\title{
Effects of kolaviron on hepatic oxidative stress in streptozotocin induced diabetes
}

\author{
Omolola R. Oyenihi ${ }^{1}$, Nicole L. Brooks ${ }^{2}$ and Oluwafemi O. Oguntibeju ${ }^{3 *}$
}

\begin{abstract}
Background: Alteration in antioxidant defence and increase in oxidative stress that results in tissue injury is characteristic of diabetes. We evaluated the protective effects of kolaviron (a flavonoid complex extracted from the seeds of Garcinia kola) on hepatic antioxidants, lipid peroxidation and apoptosis in diabetic rats.

Methods: To induce diabetes, rats were injected with streptozotocin intraperitoneally at a single dose of $50 \mathrm{mg} / \mathrm{kg}$. Kolaviron $(100 \mathrm{mg} / \mathrm{kg}$ ) was administered orally for 6 weeks (5 times weekly). Activities of liver antioxidant enzymes was analysed with Multiskan Spectrum plate reader. High performance liquid chromatography (HPLC) was used in the analysis of MDA (malondialdehyde), a product of lipid peroxidation. Apoptosis was assessed by terminal deoxynucleotidyl transferase-mediated dUTP nick end labeling (TUNEL) assay.

Result: Diabetic rats exhibited a significant increase in the peroxidation of hepatic lipids as observed from the elevated level of malondialdehyde (MDA). In addition, Oxygen Radical Absorbance Capacity (ORAC), level of reduced glutathione (GSH), ratio of reduced to oxidized glutathione (GSH: GSSG) and catalase (CAT) activity were decreased in the liver of diabetic rats. The activities of GPX (glutathione peroxidase) and SOD (superoxide dismutase) were unaltered in diabetic rats. TUNEL assay revealed increased apoptotic cell death in the liver. Kolaviron attenuated lipid peroxidation and apoptosis, increased CAT activity, GSH levels and GSH: GSSG ratio. The ORAC of kolaviron-treated diabetic liver was restored to near-normal values.
\end{abstract}

Conclusion: Kolaviron protects the liver against oxidative and apoptotic damage induced by hyperglycemia.

Keywords: Diabetes, Antioxidant, Apoptosis, Liver

\section{Background}

Diabetic patients are more predisposed to microvascular and macrovascular complications. Although the control of blood glucose and dyslipidaemia is beneficial, these therapeutic approaches cannot reverse organ damage. Reports have shown that chronic generation of reactive oxygen species (ROS) due to hyperglycemia play a critical role in the development of diabetic liver injury, hence the use of antioxidant rich plant materials in the control of diabetes has received considerable attention $[1,2]$. Due to the involvement of oxidative stress in diabetes, antioxidants might attenuate or delay the hepatic injury in diabetic patients and in experimental models. The pharmacological effects of kolaviron (KV), a flavonoid complex isolated

\footnotetext{
*Correspondence: oguntibejuo@cput.ac.za

${ }^{3}$ Nutrition and Chronic Diseases Unit, Oxidative Stress Research Centre, Department of Biomedical Sciences, Cape Peninsula University of Technology, Bellville, South Africa

Full list of author information is available at the end of the article
}

from the Garcinia kola seed (also known as bitter kola) in animal models are extensive, ranging from protection against Plasmodium berghei infection and hepatoxicity by toxins such as carbon tetrachloride [3] to glucose lowering effect [4]. The active compounds so far reported in KV includes Garcinia biflavonoid (GB) 1, GB-2, kolaflavanone, kolaflavone and binaringenin $[5,6]$. KV has been shown to reduce oxidative stress in many studies $[7,8]$. In regard to the central role of oxidative stress in the pathogenesis of diabetic liver injury, this study was designed to evaluate the effect of KV on oxidative stress and apoptosis in the liver of streptozotocin-induced diabetic rats.

\section{Methods}

\section{Animals}

The study protocol was approved by the Faculty of Health and Wellness Sciences Research Ethics Committee of the Cape Peninsula University of Technology (Ethics Certificate 
no: CPUT/HW-REC 2012/AO4). All received humane care in accordance to the criteria outlined in the 'Guide for the Care and Use of Laboratory Animals' prepared by the National Academy of Science (NAS) and published by the National Institute of Health (Publication no. 80-23, revised 1978). Male Wistar rats (11-12 weeks, $270 \pm 25$ g), were used for the study. Experiments were performed at the animal facility of the Medical Research Council (MRC) and strictly adhered to the standard operating procedures (SOPs). All animals were housed individually at room temperature $\left(22 \pm 2{ }^{\circ} \mathrm{C}\right)$ with $55 \pm 5 \%$ humidity and an automatically controlled cycle of $12 \mathrm{~h}$ light and $12 \mathrm{~h}$ dark. A standard laboratory diet and water were provided ad libitum and rats were habituated to the experimental conditions 1 week prior to experimentation.

\section{Plant materials}

Fresh seeds of Garcinia kola were purchased from Bodija market in Ibadan, Oyo State, Nigeria and authenticated by Professor E. A. Ayodele at the Department of Botany, University of Ibadan. A voucher specimen (FHI-109777) is available at the herbarium of the Forestry Research Institute of Nigeria (FRIN), Ibadan.

\section{Extraction of kolaviron (KV)}

Garcinia kola seeds were peeled, sliced and air-dried $\left(25-28{ }^{\circ} \mathrm{C}\right)$. KV was isolated according to the method of Iwu et al. [4]. The powdered seeds $(600 \mathrm{~g})$ were defatted with $800 \mathrm{ml}$ of light petroleum ether (bp 40-60 ${ }^{\circ} \mathrm{C}$ ) in a soxhlet for $24 \mathrm{~h}$. The defatted powder was spread in thin layers on trays and air dried at room temperature for $24 \mathrm{~h}$, repacked in the soxhlet and extracted with acetone $(500 \mathrm{ml})$ at a temperature of $40{ }^{\circ} \mathrm{C}$. The extract was concentrated and diluted twice its volume with distilled water and extracted with ethylacetate $(6 \times 300 \mathrm{ml})$. The concentrated ethylacetate yielded KV (12 g).

\section{Induction of diabetes}

Diabetes was induced in rats by a single intraperitoneal injection of freshly prepared solution of $50 \mathrm{mg} / \mathrm{kg}$ streptozotocin (Sigma-Aldrich, Johannesburg, SA) in citrate buffer $(0.1 \mathrm{M}, \mathrm{pH} 4.5)$ to overnight fasted rats. Diabetes was confirmed by stable hyperglycemia $(>18 \mathrm{mmol} / \mathrm{l})$ in the tail blood glucose after 5 days of streptozotocin (STZ) injection using a portable glucometer (Accu-Chek, Roche, Germany).

\section{Study design and tissue collection}

The animals were divided into 4 groups $(n=10$ per group): Normal control (C group), KV treated normal control $(\mathrm{C}+\mathrm{KV})$, diabetic control (D group) and $\mathrm{KV}$ treated diabetic group (D + KV group). Treatment was started on the 6th day post STZ injection and continued for 6 weeks. KV (100 mg/kg b.wt.), dissolved in dimethylsulphoxide (DMSO: $100 \%$ ) to a final concentration of $70 \mathrm{mg} / \mathrm{ml}$, was administered by gastric gavage 5 times a week. $100 \mathrm{mg} / \mathrm{kg}$ of $\mathrm{KV}$ was a more effective dose among the doses (100 and $200 \mathrm{mg} / \mathrm{kg}$ ) investigated in our preliminary study. The dosage of KV was adjusted every week according to any change in body weight to maintain similar dose over the period of study. At the end of experimental period, The liver was rapidly excised, washed in icecold phosphate buffered saline, blotted, frozen in liquid nitrogen, and stored at $-80{ }^{\circ} \mathrm{C}$ for biochemical estimations.

\section{Oxygen Radical Absorbance Capacity (ORAC)}

The ORAC assay was conducted to kinetically measure the peroxyl radical scavenging activity in liver samples with trolox (6-hydroxy-2,5,7,8-tetramethylchroman-2carboxylic acid) as the antioxidant standard according to the method of $\mathrm{Ou}$ et al. [9]. Liver homogenates were deproteinized with $0.5 \mathrm{M}$ perchloric acid (1:1, v/v) and centrifuged at $10,000 \mathrm{~g}$ for $10 \mathrm{~min}$. The supernatant was stored at $-80{ }^{\circ} \mathrm{C}$ prior to analysis. Fluorescein (FL) was used as the fluorescent probe and the peroxyl radicals were generated from AAPH (2,2'-azobis (2-methylpropionamidine) dihydrochloride) in $75 \mathrm{mM}$ phosphate buffer ( $\mathrm{pH}$ 7.4). Specifically, $138 \mu \mathrm{L}$ of $14 \mu \mathrm{M}$ FL solution was mixed with $12 \mu \mathrm{L}$ of diluted sample (1:20) with $75 \mathrm{Mm}$ phosphate buffer, $\mathrm{pH}$ 7.4) standard, or blank (phosphate buffer, pH 7.4) to a black 96-well flat bottom plate and the plate was incubated at $37{ }^{\circ} \mathrm{C}$ for $20 \mathrm{~min}$. After incubation, the reaction was started by the addition of $50 \mu \mathrm{L}$ of AAPH $(4.8 \mathrm{mM})$ to the mixture. Standards and samples were measured in triplicate. The fluorescence of the reaction mixture was monitored and recorded every minute (excitation $=485 \mathrm{~nm}$ and emmission $=535 \mathrm{~nm}$ ) for $2 \mathrm{~h}$ with a Fluoroscan Ascent plate reader (Thermo Fischer Scientific, Waltham, MA, USA). Results were determined by using a regression equation relating trolox concentrations and the net area under the kinetic fluorescein decay curve $(y=a x 2+b x+c)$. The ORAC value was expressed in micromoles of trolox equivalents per gram of tissue ( $\mu \mathrm{mol} \mathrm{TE} / \mathrm{g})$.

\section{Estimation of superoxide dismutase activity}

Superoxide dismutase (SOD) was determined by the method of Crosti et al. [10]. The reaction mixture in a 96well plate consisted of $15 \mu \mathrm{L}$ of sample, $170 \mu \mathrm{L}$ of $0.1 \mathrm{mM}$ DETAPAC (Diethylenetriaminepentaacetic Acid) in $50 \mathrm{Mm}$ sodium phosphate buffer ( $\mathrm{pH} 7.4$ ), and $20 \mu \mathrm{L}$ of $1.6 \mathrm{mM}$ 6-hydroxydopamine which initiated the reaction. The reaction was measured at $490 \mathrm{~nm}$ for $4 \mathrm{~min}$ at $30 \mathrm{~s}$ intervals and SOD activity expressed as $\mathrm{U} / \mathrm{mg}$ of protein.

\section{Estimation of glutathione peroxidase activity}

Activities of antioxidant enzymes were determined in a clear 96-well plate using a Multiskan Spectrum plate 
reader (Thermo Fisher Scientific, USA). Glutathione peroxidase (GPx) activity was determined according to the method of Ellerby \& Bredesen [11]. To initiate the reaction, $25 \mu \mathrm{L}$ of $\mathrm{H}_{2} \mathrm{O}_{2}(15 \mathrm{mM})$ was added to a final reaction mixture containing $2.5 \mu \mathrm{L}$ of GSH $(0.1 \mathrm{M}), 2.5 \mu \mathrm{L}$ of GR $(0.1$ $\mathrm{U} / \mathrm{mL}), 5 \mu \mathrm{L}$ liver homogenate, $5 \mu \mathrm{L}$ of NADPH $(15 \mathrm{mM}$ in $0.1 \% \mathrm{NaHCO}), 2.5 \mu \mathrm{L}$ of sodium azide $(100 \mathrm{mM})$ and $210 \mu \mathrm{L}$ of assay buffer $(50 \mathrm{mM}$ potassium phosphate, $1 \mathrm{mM}$ EDTA (Ethylenediaminetetraacetic acid), pH 7.0. The rate of $\mathrm{H}_{2} \mathrm{O}_{2}$-dependent oxidation of NADPH was monitored at $340 \mathrm{~nm}$ at $30 \mathrm{~s}$ intervals for $2 \mathrm{~min}$. The activity of GPx was calculated using the extinction coefficient of $6.22 \mathrm{mM}-1 \mathrm{~cm}-1$ and results expressed as nmol NADPH oxidized per min per $\mu \mathrm{g}$ protein.

\section{Estimation of catalase activity}

Catalase (CAT) activity was determined by the method of Aebi [12]. The assay is based on the principle of measurement of decomposition of hydrogen peroxide $\left(\mathrm{H}_{2} \mathrm{O}_{2}\right)$ by catalase measured at $240 \mathrm{~nm}$. Assay mixture contained $5 \mu \mathrm{L}$ of sample, $170 \mu \mathrm{L}$ of $50 \mathrm{mM}$ potassium phosphate ( $\mathrm{pH} 7.0)$ and $50 \mu \mathrm{L}$ of $0.1 \%$ hydrogen peroxide in $50 \mathrm{mM}$ potassium phosphate ( $\mathrm{pH} 7.0)$. The rate of decomposition of $\mathrm{H}_{2} \mathrm{O}_{2}$ was measured at $240 \mathrm{~nm}$ for $2 \mathrm{~min}$ in $15 \mathrm{~s}$ intervals in a Multiskan Spectrum plate reader (Thermo Fisher Scientific, USA). Catalase activity is expressed as $\mathrm{mol} \mathrm{H}_{2} \mathrm{O}_{2}$ consumed/min/mg protein.

\section{Glutathione status analysis}

Glutathione (GSH and GSSG) status was determined according to the method of Asensi et al. [13]. Liver samples were homogenized $(1: 10)$ in $6 \%(v / v)$ Perchloric acid (PCA) containing $1 \mathrm{mM}$ EDTA for reduced glutathione (GSH) determination and for oxidized glutathione (GSSG) determination, liver samples were homogenized in $6 \%$ PCA containing freshly prepared $3 \mathrm{Mm}$ M2VP (1-methyl2-vinylpyridinium trifluoromethanesulfonate) and $1 \mathrm{Mm}$ EDTA (Ethylenediaminetetraacetic acid). Homogenates were centrifuged at $15,000 \mathrm{~g}$ for $5 \mathrm{~min}, 50 \mu \mathrm{L}$ of supernatant was added to $50 \mu \mathrm{L}$ of $0.3 \mathrm{mM}$ DTNB (5,5' -dithio bis-2-nitrobenzoic acid) and $50 \mu \mathrm{L}$ of glutathione reductase (1U). The reaction was initiated by addition of $50 \mu \mathrm{L}$ of $1 \mathrm{mM} \mathrm{NADPH}$ and change in absorbance was monitored at $410 \mathrm{~nm}$ for $5 \mathrm{~min}$. GSH and GSSG Levels were calculated using GSH and GSSG as standards.

\section{Estimation of lipid peroxidation}

Liver malondialdehyde (MDA) was determined by HPLC using a method adapted from Khoschsorur et al. [14]. Briefly, $100 \mu \mathrm{L}$ of liver homogenates and standard were
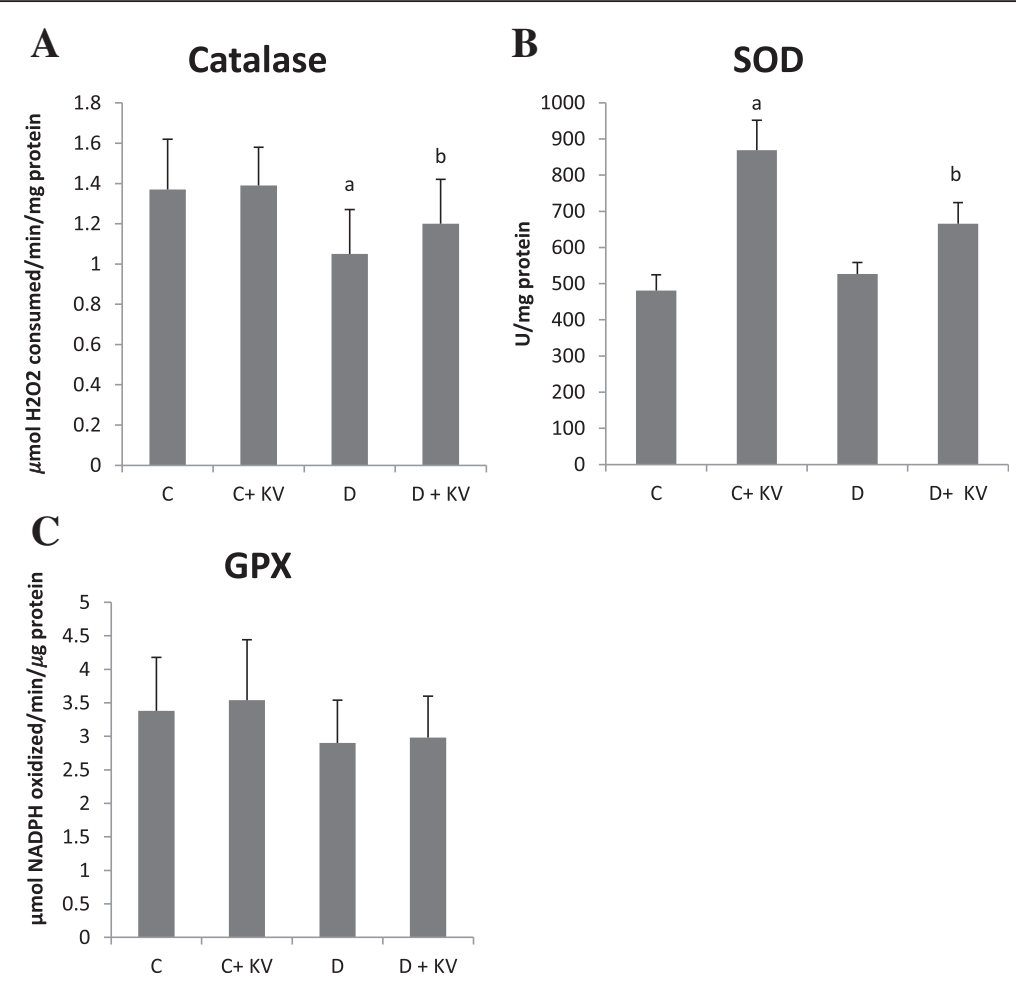

Fig. 1 a-c Effects of KV on the activities of antioxidant enzymes; catalase (CAT), superoxide dismutase (SOD) and glutathione peroxidase (GPX) in the hepatic tissues of experimental rats. Data are presented as mean \pm S.D. a Values differ significantly from those of control $(p<0.05)$. $b$ Values differ significantly from diabetic group $(p<0.05)$. C Non-diabetic control rats, $C+K V$ kolaviron-treated control rats, $D$ untreated diabetic rats, $D+$ KV kolaviron-treated diabetic rats 
mixed with $750 \mu \mathrm{L}$ orthophosphoric acid $(0.44 \mathrm{M})$, $250 \mu \mathrm{L}$ of $42 \mathrm{mM}$ aqueous TBA (thiobarbituric acid) and $450 \mu \mathrm{L}$ distilled water. The mixture was heated in a boiling water bath for $60 \mathrm{~min}$. After cooling on ice, alkaline methanol ( $50 \mathrm{ml}$ methanol $+4.5 \mathrm{ml} 1 \mathrm{M} \mathrm{NaOH}$ ) was added (1:1). The samples were centrifuged at $3500 \mathrm{~g}$ for $3 \mathrm{~min}$ at $4{ }^{\circ} \mathrm{C}$. $1 \mathrm{~mL}$ of supernatant was added to $500 \mu \mathrm{L}$ of $\mathrm{n}$ hexane and the mixture centrifuged at $14,000 \mathrm{~g}$ for $40 \mathrm{~s}$. $50 \mu \mathrm{L}$ of the supernatant was then chromatographed on an Agilent 1200 series HPLC. A $5 \mu$ m YMC-PackPro C18 (1 5 $0 \mathrm{~m} \mathrm{~m} \times 4.6 \mathrm{~m} \mathrm{~m}$ i.d.) column was used for separation with 60:40 (v/v) $50 \mathrm{mM}$ phosphate buffer, $\mathrm{pH}$ 6.8-methanol as mobile phase. The flow rate was $1 \mathrm{~mL} \min -1$. Fluorometric detection was performed with excitation at $532 \mathrm{~nm}$ and emission at $552 \mathrm{~nm}$. The peak of the MDA-TBA adduct was calibrated with the MDA standard.

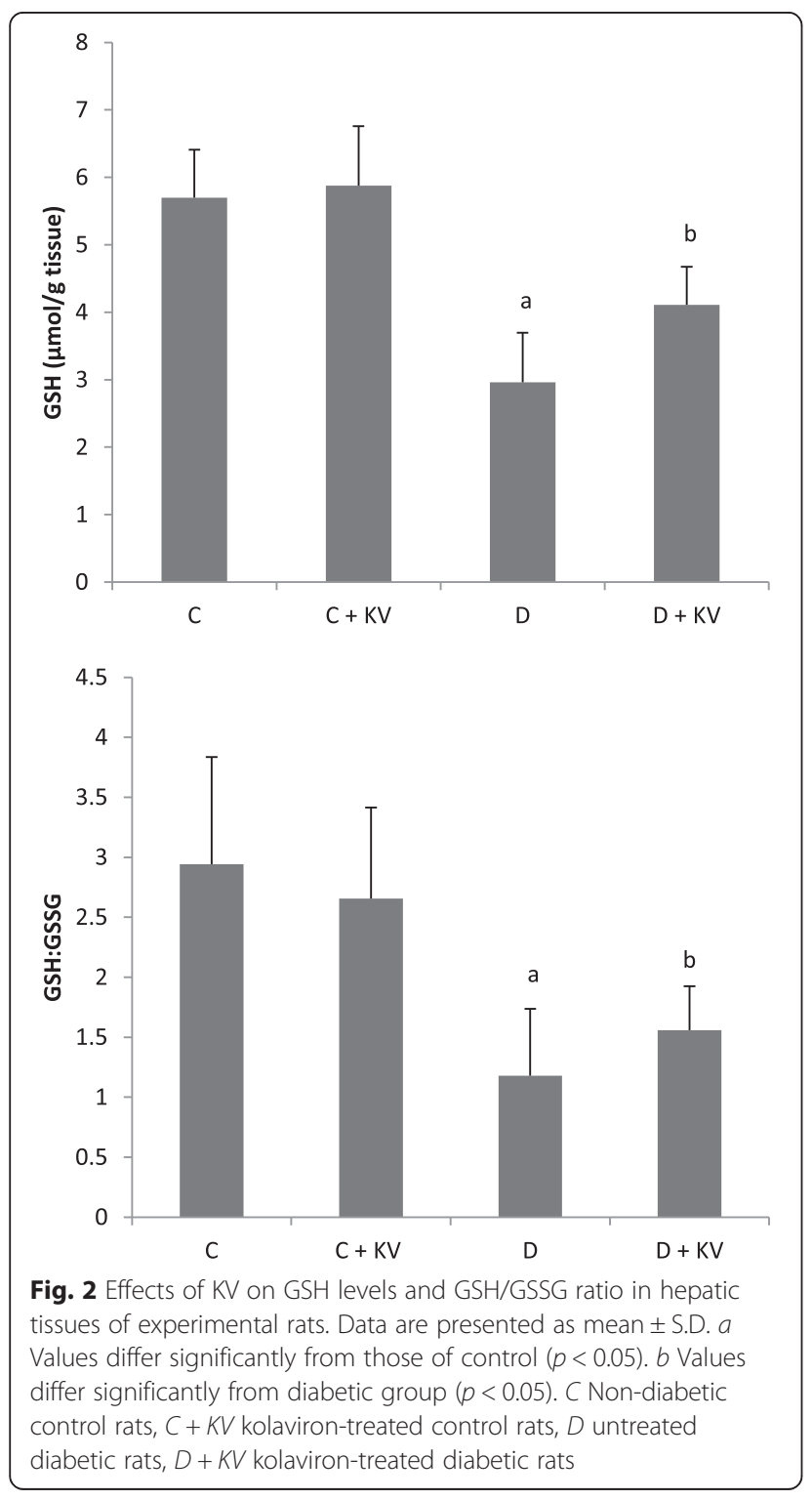

Terminal deoxynucleotidyl transferase-mediated dUTP nick end labeling (TUNEL) assay

For detection of apoptotic cells, liver sections were stained with the reagents supplied by ApopTag fluorescein. In situ Apoptosis Detection Kit (Chemicon, Billerica, CA). Briefly, each slide was deparaffinized, rehydrated, and treated with proteinase $\mathrm{K}(20 \mathrm{mg} / \mathrm{L})$ for $15 \mathrm{~min}$. Equilibration buffer was applied directly on the slides followed by incubation with the TUNEL reaction mixture containing terminal deoxynucleotidyl transferase (TdT) and digoxigenin nucleotide and unlabeled nucleotide for $1 \mathrm{~h}$ in a humidified chamber at $37{ }^{\circ} \mathrm{C}$. Sections were counter stained with a mounting medium containing $0.5 \mu \mathrm{g} / \mathrm{mL}$ of propidium iodide and viewed by Olympus IX-81 microscope. Apoptotic cell death was quantitatively analyzed by counting TUNEL positive cells selected randomly from five consecutive fields at $\times 10$ using the image analysis software 'Image)'. TUNEL positive cells were expressed as percentage of total cells.

\section{Statistical analysis}

Data were expressed as the means \pm standard deviation. Significant differences between mean values of different groups were determined by one-way analysis of variance (ANOVA) with MedCalc software. Data not normally distributed was log transformed and analyzed using the Kruskal-Wallis one-way ANOVA on ranks hypotheses. Differences were considered significant at $p<0.05$.

\section{Results}

The effects of KV on antioxidant status of experimental rats are shown in Figs. 1, 2, 3, 4. Although no change was observed in the activities of glutathione peroxidase and superoxide dismutase, catalase activity was decreased in diabetic tissues and normalized following KV

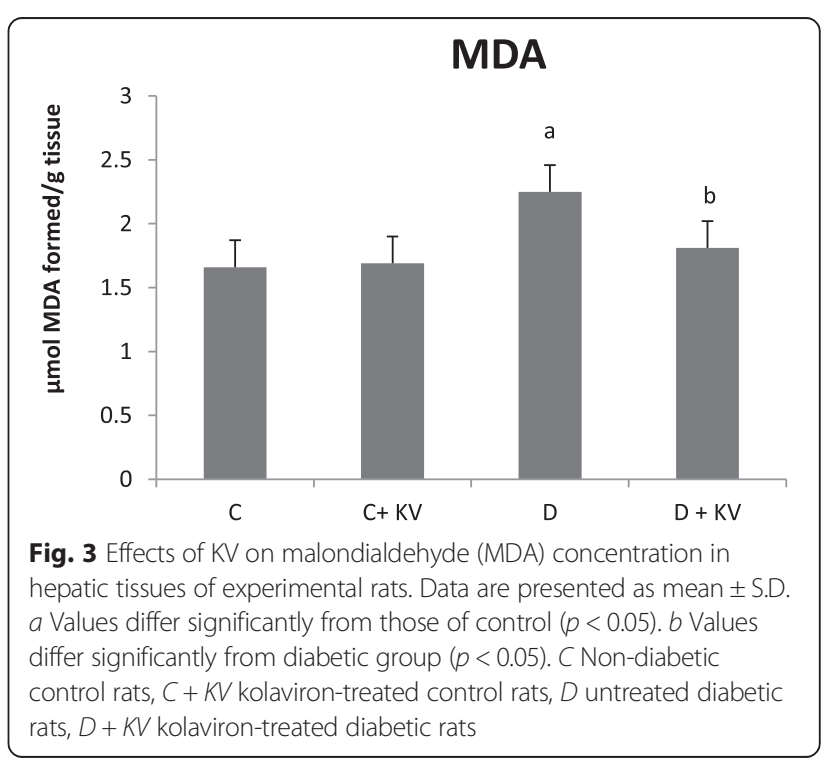




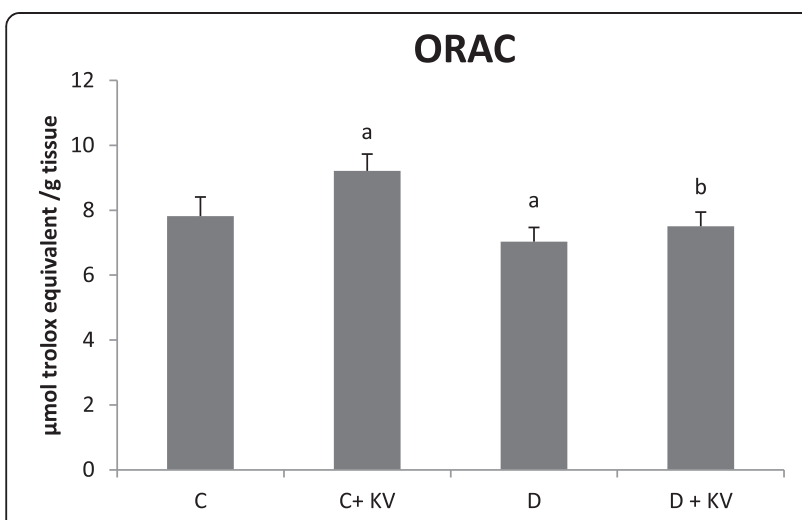

Fig. 4 Effects of KV on oxygen radical absorbance capacity (ORAC) in hepatic tissues of experimental rats. Data are presented as mean \pm S.D. $a$ Values differ significantly from those of control $(p<0.05)$. $b$ Values differ significantly from diabetic group $(p<0.05)$. C Non-diabetic control rats, $C+K V$ kolaviron-treated control rats, $D$ untreated diabetic rats, $D+K V$ kolaviron-treated diabetic rats

administration (Fig. 1a-c). However, KV increased activity of superoxide dismutase in diabetic rats. Oxygen radical absorbing capacity (ORAC) was reduced significantly in diabetic rats but elevated after KV administration (Fig. 4). KV also boosted ORAC in normal rats. GSH level and GSH/GSSG ratio decreased in hepatic tissues of diabetic rats (Fig. 2). Treatment with KV improved these alterations as observed from increased levels of GSH and GSH/GSSG ratio in comparison to diabetic control group.
The concentration of lipid peroxidation marker, malondialdehyde $(\mathrm{MDA})$ was significantly $(P<0.05)$ higher in diabetic control group. Treatment of diabetic rats with $\mathrm{KV}$ decreased hepatic MDA concentration (Fig. 3).

Examination of hepatic apoptosis with TUNEL staining revealed an increase of TUNEL positive cells in the liver sections of diabetes control group (Fig. 5). KV reduced apoptotic cells in the liver of diabetic rats.

\section{Discussion}

Oxidative stress-an imbalance between the generation of reactive oxygen species (ROS) and the compensatory response from the endogenous antioxidant network, has been demonstrated to play a pivotal role in diabetic vascular complications [15]. Therefore, it has been proposed that scavengers of oxidative stress may have a positive effect in alleviating diabetes as well as reduce its secondary complications. Antioxidants like superoxide dismutase (SOD), catalase (CAT), glutathione peroxidase (GPX) and reduced glutathione (GSH) effectively forms a defensive alliance against the onslaught of ROS protecting cells from oxidative damage. Reports have shown variation in the activities of antioxidant enzymes in diabetic rats. Although reductions of enzyme activities have been reported, some studies also demonstrated an increase and no change in enzyme activities. Possible reasons for the contradictory reports are variation in disease severity, duration, tissue specificity or other experimental conditions [16].

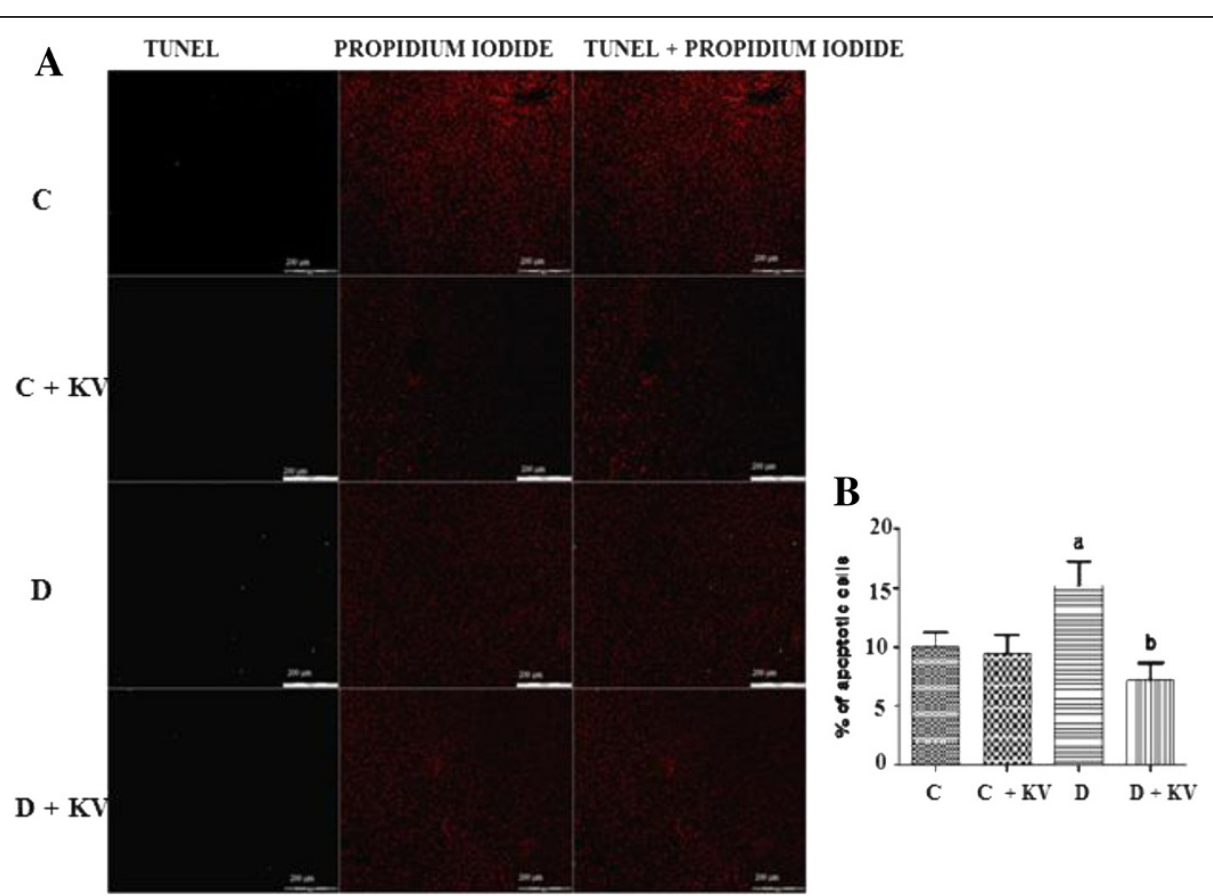

Fig. $\mathbf{5}$ a and $\mathbf{b}$ Effects of KV on apoptosis in the hepatic tissues of experimental rats. Data are presented as mean \pm S.D. $a$ Values differ significantly from those of control $(p<0.05)$. $b$ Values differ significantly from diabetic group $(p<0.05)$. C Non-diabetic control rats, $C+K V$ kolaviron-treated control rats, $D$ untreated diabetic rats, $D+K V$ kolaviron-treated diabetic rats 
The enzymatic antioxidant-catalase (CAT) is involved in the removal of hydrogen peroxide in living cells and protects against hydroxyl radicals toxicity. In the present study, a significant decrease in CAT activity in diabetic rats may reflect the inability of the liver to eliminate hydrogen peroxide, a ROS. KV treatment enhanced CAT activities, demonstrating the antioxidant and tissue protective effects of KV.

Activities of SOD and GPX were not significantly different in diabetic controls compared to non-diabetic rats. KV increased SOD activity in both normal and diabetic rats. Superoxide dismutase (SOD) is an important antioxidant defence that catalyse the breakdown of superoxide radical anion. The increase activity of SOD in diabetic and nondiabetic rats after KV treatment might be a mechanism to boost antioxidant defence. There is a report of increased mRNA expression of SOD in cultured interstitial Leydig cells (ILCs) in the presence of KV [7]. The increase activity of SOD was accompanied by an increase in oxygen radical absorbing capacity (ORAC), further supporting the protective role of $\mathrm{KV}$ against free radicals.

Glutathione is the most abundant non enzymatic intracellular antioxidant [17]. Depletion of reduced Glutathione (GSH) either by conjugation and removal from the cell or oxidation to GSSG could significantly affect the overall redox potential of the cell [18]. The beneficial role of glutathione as an antioxidant depends not only on the glutathione pool size but also on its reduction/oxidation status [19]. The ratio of GSH to GSSG is a sensitive indicator of oxidative stress. In the present study, diabetic state resulted in a significant depletion of GSH level and GSH/GSSG ratio indicating its increased utilization against reactive oxygen species generated in diabetic rats. An elevation of the GSH stores and GSH/GSSG ratio in the liver of diabetic rats treated with KV compared to diabetic control suggests the alleviation of free radical damage.

An elevated level of liver MDA, a product of lipid peroxidation, has been reported in diabetic rats [20-23]. Results from our study corroborate these observations. KV treatment of diabetic rats reduced lipid peroxidation indicating its free radical scavenging property.

Apoptosis, a programmed cell death although occurs normally to maintain tissue homeostasis, it can become uncontrolled or dysregulated leading to deleterious pathological consequences such as diabetes [24]. Several studies have shown a positive relationship between hyperglycemiainduced oxidative stress and apoptosis [25-28]. Jaeschke et al. also demonstrates that the diabetic state increased oxidative stress and cell death of hepatocytes and endothelial cells [29]. Similarly, our work corroborates these observations as apoptosis was significantly increased in the liver post-streptozotocin injection. Treatment with KV however, protected hepatic cells from apoptotic death suggesting the anti-apoptotic property of KV.

\section{Conclusions}

The present study explored the effect of KV on oxidative stress and diabetic liver injury and the resultsdemonstrated that KV treatment of diabetic rats protected against hyperglycemia-induced apoptosis andpromoted survival of hepatocytes, perhaps by scavenging free radicals.

\section{Competing interests}

The authors declare that they have no competing interests.

\section{Authors' contributions}

ORA was responsible for the conception and design, carried out all experiment, performed data analysis and drafted the manuscript. NLB and 000 made contribution to the conception and revised the manuscript critically for intellectual content. All authors read and approved the final manuscript

\section{Acknowledgement}

This study was supported by the University Research Fund (URF) of the Cape Peninsula University of Technology.

\section{Author details}

${ }^{1}$ Department of Biochemistry, Bowen University, Iwo, Nigeria. ${ }^{2}$ Department of Wellness Sciences, Cape Peninsula University of Technology, Cape Town, South Africa. ${ }^{3}$ Nutrition and Chronic Diseases Unit, Oxidative Stress Research Centre, Department of Biomedical Sciences, Cape Peninsula University of Technology, Bellville, South Africa.

Received: 30 January 2015 Accepted: 2 July 2015

Published online: 16 July 2015

\section{References}

1. Bakhshaeshi M, Khaki A, Fathiazad F, Khaki AA, Ghadamkheir E. Anti-oxidative role of quercetin derived from Allium cepa on aldehyde oxidase (OX-LDL) and hepatocytes apoptosis in streptozotocin-induced diabetic rat. Asian Pac J Trop Biomed. 2012;2(7):528-31.

2. Dey A, Lakshmanan J. The role of antioxidants and other agents in alleviating hyperglycemia mediated oxidative stress and injury in liver. Food Funct. 2013:4(8):1148-84.

3. Farombi EO. Mechanisms for the hepatoprotective action of kolaviron: Studies on h epatic enzymes, microsomal lipids and lipid peroxidation in carbon tetrachloride-treated rats. Pharmacol Res. 2000;42:75-80.

4. Iwu MM, Igboko OA, Okunji CO, Tempesta MS. Antidiabetic and aldose reductase 248 activities of biflavanones of Garcinia kola. J Pharm Pharmacol. 1990;42(4):290-2.

5. Iwu M. Antihepatoxic constituents of Garcinia kola seeds. Experientia. 1985;41(5):699-700.

6. Ayepola OR, Chegou NN, Brooks NL, Oguntibeju OO. Kolaviron, a Garcinia biflavonoid complex ameliorates hyperglycemia-mediated hepatic injury in rats via suppression of inflammatory responses. BMC Complement Altern Med. 2013;13:363.

7. Abarikwu SO, Farombi EO, Pant AB. Kolaviron biflavanoids of Garcinia Kola seeds protect atrazine-induced cytotoxicity in primary cultures of rat leydig cells. Int J Toxicol. 2012;31(4):407-15.

8. Adedara IA, Farombi EO. Influence of kolaviron and vitamin $\mathrm{E}$ on ethylene glycol monoethyl ether induced haematotoxicity and renal apoptosis in rats. Cell Biochem Funct. 2013;32(1):32-8.

9. Ou B, Hampsch-Woodill M, Prior RL. Development and validation of an improved oxygen radical absorbance capacity assay using fluorescein as the fluorescent probe. J Agric Food Chem. 2001;49(10):4619-26.

10. Crosti N, Servidei T, Bajer J, Serra A. Modification of the 6-hydroxydopamine technique for the correct determination of superoxide dismutase. J Clin Chem Clin Biochem. 1987;25(4):265-6.

11. Ellerby LM, Bredesen DE. Measurement of cellular oxidation, reactive oxygen species and antioxidant enzymes during apoptosis. Methods Enzymol. 2000;322:413-21.

12. Aebi H. Catalase in vitro. Methods Enzymol. 1984;105:121-6. 
13. Asensi M, Sastre J, Pallardo FV, Lloret A, Lehner M, Garcia-de-la Asuncion J, et al. Ratio of reduced to oxidized glutathione as indicator of oxidative stress status and DNA damage. Methods Enzymol. 1998;299:267-76.

14. Khoschsorur GA, Winklhofer-Roob BM, Rabl H, Auer T, Peng Z, Schaur RJ. Evaluation of a sensitive HPLC method for the determination of malondialdehyde, and application of the method to different biological materials. Chromatographia. 2000;52:181-4.

15. Ceriello A. Oxidative stress and glycaemic regulation. Metabolism. 2000;49:27-9.

16. Essani NA, McGuire GM, Manning AM, Jaeschke H. Endotoxin-induced activation of the nuclear transcription factor NF-kB in hepatocytes, Kupffer cells and endothelial cells in vivo. J Immunol. 1996;156:2956-63.

17. Livingstone C, Davis J. Review: targeting therapeutics against glutathione depletion in diabetes and its complications. Br J Diabetes Vasc Dis. 2007;7(6):258-65.

18. Yadav P, Sarkar S, Bhatnagar D. Action of Capparis deciduas against alloxaninduced oxidative stress and diabetic in rat tissues. Pharmacol Res. 1997;36:221-8.

19. Meister A. Strategies for increasing cellular glutathione. In: Packer L, Cadenas E, editors. Biothiols in health and disease. New York, NY: Marcel Dekker Inc; 1995. p. 165-88.

20. Kumar S, Vasudeva N, Sharma S. GC-MS analysis and screening of antidiabetic, antioxidant and hypolipidemic potential of Cinnamomum tamala oil in streptozotocin induced diabetes mellitus in rats. Cardiovasc Diabetol. 2012;11:95.

21. Kumar V, Ahmed D, Verma A, Anwar F, Ali M, Mujeeb M. Umbelliferone beta-D-galactopyranoside from Aegle marmelos (L.) corr. An ethnomedicinal plant with antidiabetic, antihyperlipidemic and antioxidative activity. BMC Compl Alternative Med. 2013;13(1):273.

22. Oršolić N, Sirovina D, Končić MZ, Lacković G, Gregorović G. Effect of Croatian propolis on diabetic nephropathy and liver toxicity in mice. BMC Compl Alternative Med. 2012;12(1):117.

23. Thomson M, Al-Qattan K, Mansour MH, Ali M. Green tea attenuates oxidative stress and downregulates the expression of angiotensin II AT 1 receptor in renal and hepatic tissues of streptozotocin-induced diabetic rats. Evid base Compl Alternative Med. 2012;409047:1-10.

24. Kim YJ, Kim Y, Yokozawa T. Pycnogenol modulates apoptosis by suppressing oxidative stress and inflammation in high glucose-treated renal tubular cells. Food Chem Toxicol. 2011;49(9):2196-201.

25. Park KS, Kim JH, Kim MS, Kim JM, Kim SK, Choi JY, et al. Effects of insulin and antioxidant on plasma 8-hydroxyguanine and tissue 8hydroxydeoxyguanosine in streptozotocin-induced diabetic rats. Diabetes. 2001;50(12):2837-41.

26. Francés DE, Ronco MT, Monti JA, Ingaramo PI, Pisani GB, Parody JP, et al. Hyperglycemia induces apoptosis in rat liver through the increase of hydroxyl radical: new insights into the insulin effect. J Endocrinol. 2010;205(2):187-200.

27. Gürpınar T, Ekerbiçer N, Uysal N, Barut T, Tarakçı F, Tuglu MI. The effects of the melatonin treatment on the oxidative stress and apoptosis in diabetic eye and brain. The Sci World J. 2012;498489:1-5.

28. Spies L, Koekemoer TC, Sowemimo AA, Goosen ED, Van de Venter M. Caspase-dependent apoptosis is induced by Artemisia afra Jaca. ex Willd in a mitochondria-dependent manner after G2/M arrest. S Afric J Bot. 2013;84:104-9.

29. Jaeschke $H$. Reactive oxygen and mechanisms of inflammatory liver injury. J Gastroenterol Hepatol. 2000;15(7):71

\section{Submit your next manuscript to BioMed Central and take full advantage of:}

- Convenient online submission

- Thorough peer review

- No space constraints or color figure charges

- Immediate publication on acceptance

- Inclusion in PubMed, CAS, Scopus and Google Scholar

- Research which is freely available for redistribution 